\title{
KAJIAN LITERATUR PSIKOLOGI: KATARSIS SEBAGAI BENTUK EKSPRESIF DIRI MAHASISWA PADA MASA PANDEMI COVID-19
}

\author{
Nisrina Rahmawati \\ Program Studi Psikologi, Fakultas Kedokteran, Universitas Lambung Mangkurat \\ Email: 2010914120012@mhs.ulm.ac.id
}

\begin{abstract}
ABSTRAK
Pandemi COVID-19 tak terasa sudah hampir menginjak setahun beraksi dan menunjukkan eksistensinya di permukaan bumi, termasuk di Indonesia. Tercatat, sudah banyak memakan korban dan menimbulkan dampak kerugian baik perindividu sampai ke golongon kelompok atau skala negara. Sebagai makhluk sosial-yang tak bisa hidup tanpa bantuan orang lain, tentulah dalam kondisi terbatas sekarang ini banyak disiasati menjalin interaksi sosial menggunakan media daring dan tidak bertatap muka secara langsung karena dikhawatirkan semakin meninnginya angka pandemi yang berasal dari China tersebut. Kendati demikian, manusia tetap harus menjalin interaksi terhadap sesamanya guna melanjutkan aktivitas kehidupan, dalam setiap interaksi baik aktivitas di lingkungan primer seperti keluarga, lingkungan sekunder, dan lingkungan tersier pastilah seringkali memunculkan emosi-emosi yang terpendam karena adanya gesekan saat interaksi terjalin atau komunikasi yang tak sejalan. Artikel ini bertujuan memberikan sudut pandang tentang mengekspresikan penyaluran emosiemosi diri melalui metode katarsis di masa pandemi COVID-19 bagi mahasiswa.
\end{abstract}

Kata Kunci: Katarsis, Ekspresi, Covid-19, Psikologi

\begin{abstract}
The COVID-19 pandemic has almost reached a year of action and shows its existence on the surface of the earth, including in Indonesia. It has been noted that it has claimed many victims and caused losses both by individuals to groups or on a national scale. As a social being - who cannot live without the help of others, of course, in limited conditions nowadays, there are many ways to establish social interactions using online media and not meet face to face because it is feared that the pandemic figure originating from China will increase. However, humans
\end{abstract}


still have to interact with each other in order to continue their life activities, in every interaction both activities in the primary environment such as family, secondary environment, and tertiary environment must often bring up pent up emotions due to friction when interactions are established or communication is not in line. This article aims to provide a point of view on expressing the channeling of one's emotions through the catharsis method during the COVID19 pandemic for students.

Keywords: Catharsis, Expression, Covid-19, Psychology

\section{PENDAHULUAN}

Istilah 'katarsis' berasal dari Bahasa Yunani yaitu kathoros bermakna 'untuk membersihkan' atau 'menyucikan'. Kali pertama teori katarsisi diperkenalkan yaitu pada tahun 1960 dalam Journal if abnormal social psychology yang berjudul "The Stimulating "Versus Chatartic Effect of a Vicarious Aggressive Activity”. Konsep teori katarsis berdiri atas dasar teori psikoanalisa milik Sigmund Freud, yang menyatakan bahwa emosi yang tertahan atau dipendam bisa mengakibatkan ledakan emosi yang berlebihan. Oleh sebab itu, diperlukan adanya penyaluran emosi yang dipendam tersebut. Teori katarsis juga menyebutkan bahwa penyaluran emosi dengan katarsis memberikan individu yang cenderung keras menyalurkan emosinya dengan cara yang tidak merugikan dan tendensi melakukan serangan terhadap orang lain [1].
Pada dasarnya katarsis adalah penyaluran emosi yang dipendam menggunakan berbagai cara yang tidak merugikan. Dalam pengaplikasiannya, katarsis memiliki tujuan untuk memecahkan masalah yang ada, dapat menemukan proses menjadi diri sendiri atau individuasi, makna hidup yang dicari, dan altered state of consciousness (ASC) adalah kesadaran yang berubah atau berbeda dengan kesadaran orang dalam keadaan normal. Menurut (Elvina, 2005) Katarsis bermanfaat untuk menghilangkan atau merubah kebiasaan, menghilangkan kepercayaan negatif, mengurangi rasa sakit, memasukkan sugesti positif, mengurangi stress pasca trauma, dan membuat jiwa menjadi tenang [2]. Esensi katarsis menurut Hurlock (2007) mengeluarkan energi emosional yang menganggu dan membersihkan tubuh serta jiwa dengan cara mengangkat sebab yang terpendam dan kemudian mencari cara mengekspresikan dorongan yang terpendam tersebuh, 
sehingga dapat mengembangkan pandangan hidup yang menyeluruh.

\section{PEMBAHASAN}

Menulis. Metode katarsis yang terkenal satu ini dilakukan dengan mengekspresikan emosi atau perasaan melalui tulisan-tulisan sebagai bentuk perwakilan penyaluran emosi. Penyingkapan emosi yang dialami saat sedang menulis pengalaman emosional dianggap sebagai faktor yang menghasilkan efek teraupetik. Menurut Pennebaker (1997) Proses teraupetik berpusat pada penyingkapan (disclosure) pengalamanpengalaman emosional, penyingkapan diri dan pengakuan merupakan proses dasar yang muncul dalam psikoterapi dan secara alamiah muncul dalam interaksi sosial yang dianggap membawa manfaat secara psikologis dan bahkan fisik [3].

Menulis bisa dilakukan dengan cara membuat buku harian setiap harinya dengan menyalurkan emosi-emosi yang dirasakan pada hari tersebut. Sebuah penelitian menunjukkan bahwa menulis buku harian dapat membawa dampakdampak positif [4] dan tentunya dengan kita menulis kita juga melatih konsistensi manajemen diri [5]. Namun, sayangnya tidak semua gemar menulis atau pandai dalam merangkai kata-kata. Padahal menurut Abbas, E. W. (2020) menulis itu sangat mudah karena sejatinya kita semua adalah penulis; semua yang dapat dilihat menggunakan panca indra yaitu melihat, mendengar, mencium, merasakan, dan meraba, informasi yang kita dapat tersebut kita tuliskan ke dalam otak dan kemudian informasi-informasi dari otak tersebut kita tuangkan ke dalam rangkaian tulisanitulah yang disebut tulisan atau kegiatan menulis [6]. Dalam masa pandemi COVID19 sekarang ini, dapat menuliskan tematema yang relevan dengaan keadaan dan emosi seperti buku yang berjudul Menulis di Kala Badai COVID-19 [7] atau meneliti tentang dampak-dampak COVID-19 [8], tentunya selain menyalurkan emosi juga dapat menyalurkan kreativitas yang dapat digunakan tak hanya oleh diri sendiri.

Menulis merupakan hal yang tak terpisahkan dari kehidupan mahasiswa, terlebih lagi mahasiswa yang telah mulai terbiasa dengan tugas-tugas kepenulisan. Seperti yang diketahui, bukan rahasia umum lagi bahwa kegiatan tulis menulis sarat dengan dampak-dampak positif yang dibawa. Sebagai mahasiswa, sudah sepatutnya menulis mampu dijadikan salah satu ajang pelepasan stress atau penyaluran emosi, terutama keterampilan tersebut sangat perlu digunakan dikondisi sekarang yang serba daring, menulis dalam ruang lingkung mahasiswa sangat beragam cakupannya, bisa menjadikan tema organisasi yang mereka ikuti sebagai bahan 
kajian [9], prokrastinasi akademik yang dihadapi [10], regulasi diri dalam perkuliahan [11], hubungan antara orangtua dan kepercayaan diri [12], kecerdasan emosi [13], motivasi belajar [14],tentunya banyak topik-topik pembahasan lainnya yang dapat dijadikan para mahasiswa sebagai referensi untuk menulis ilmiah dalam substantsi berkatarsis.

Menulis bagi mahasiswa di masa pandemi COVID-19 yang rentan stress karena pembelajaran daring ataupun aktivitas yang terbatas, tentu selain dengan menuliskannya di lembaran kertas, mahasiswa juga dapat menuliskan kartasisnya melalui sosial media tentunya dengan batasan yang tepat karena ternyata media sosial dapat dijadikan salah satu penyaluran ekspresif diri [15].

\section{KESIMPULAN}

Katarsis merupakan metode pembersihan atau penyucian diri dari emosi yang terpendam. Pada masa COVID-19 yang sarat dengan aktivitas dan pembelajaran daring, sangat penting bagi mahasiswa untuk tetap menjaga kestabilan emosinya, salah satu cara penyaluran emosi yang terpendam yaitu dengan menuliskan perasaan atau kejadian-kejadian pada buku harian, lembaran kertas, atau di media sosial dengan batasan yang tepat tentunya.

\section{DAFTAR PUSTAKA}

[1] Wahyuningsih, S. (2017). Teori katarsis dan perubahan sosial. Jurnal Komunikasi, 11(1), 39-52.

[2] Fitriani, E. (2014). PEMANFAATAN TERAPI KATARSIS DALAM MENGATASI TRAUMATIS PADA KLIEN DI YOGA ATMA CONSULTING

PEKANBARU (Doctoral dissertation, Universitas Islam Negeri Sultan Sarif Kasim Riau).

[3] Qonitatin, N., Widyawati, S., \& Asih, G. Y. (2011). Pengaruh katarsis dalam menulis ekspresif sebagai intervensi depresi ringan pada mahasiswa. Jurnal Psikologi, 9(1).

[4] Lestari, S., \& Hasanah, N. MENULIS BUKU HARIAN SEBAGAI MEDIA KATARSIS STRES

REMAJA PELAYANAN SOSIAL.

[5] Abbas, E. W. (2020). Ersis Writing Theory: Cara Mudah Menulis.

[6] WARMANSYAH ABBAS, E. R. S. I. S. (2020). Menulis di Era Covid-19: Memanage 
Trauma

Psikologis

Menghindari Psikosomatis.

Menulis di Era Covid-19:

Memanage

Trauma

Psikologis Menghindari

Psikosomatis.

[7] Abbas, E. W., \& Erlyani, N. (2020). Menulis di Kala Badai Covid-19.

[8] Shadiqi, M. A., Hariati, R., Hasan, K. F. A., I'anah, N., \& Al Istiqomah, W. (2020). Panic buying pada pandemi COVID-19: Telaah literatur dari perspektif psikologi. Jurnal Psikologi Sosial.

[9] Rachmah, D. N., Mayangsari, M. D., \& Akbar, S. N. (2015). Motivasi belajar sebagai mediator hubungan kecerdasan adversitas dan prokrastinasi akademik pada mahasiswa yang aktif berorganisasi. Jurnal Cakrawala Pendidikan, 34(2).

[10] Thoria, A., Dewi, R. S., \& Rachmah, D. N. (2020). HUBUNGAN ANTARA PENETAPAN TUJUAN DENGAN PROKRASTINASI AKADEMIK PADA
SISWA SMKN

BANJARBARU. Jurnal Kognisia: Jurnal Mahasiswa Psikologi Online, 2(2), 1824.

[11] Husna, T. A., Mayangsari, M. D., \& Rachmah, D. N. (2018). Peranan Kecerdasan Spiritual Terhadap Regulasi Diri Dalam Belajar Pada Santriwati Di SMP Darul Hijrah Puteri Martapura. Jurnal Ecopsy, 5(1), 51-56.

[12] Cimi, A., Erlyani, N., \& Rahmayanti, D. (2016). Pola Asuh Orang Tua Dengan Kepercayaan Diri Anak. Dunia Keperawatan: Jurnal Keperawatan dan Kesehatan, 1(1), 57-63.

[13] Akbar, S. N. (2016). Hubungan antara kecerdasan emosi dengan stres kerja pada perawat. Jurnal Ecopsy, 1(1).

[14] Rachmah, D. N., Mayangsari, M. D., \& Akbar, S. N. (2015). Motivasi belajar sebagai mediator hubungan kecerdasan adversitas dan prokrastinasi akademik pada mahasiswa yang aktif berorganisasi. Jurnal 
Cakrawala Pendidikan, 34(2).

[15] Nurudin, U. M. M. (2015). Media Sosial Sebagai Katarsis Mahasiswa. Komunikator, 7 (2). 